\title{
Shipping and Invasion of Second-Hand Vehicles in West African Ports: Analysing the Factors and Market Effects at the Port of Abidjan
}

\author{
Nomel Paul Stephane Essoh \\ Department of Transportation Economics and Maritime Management, School of Economics and Management, Shanghai Maritime \\ University, Shanghai, China. \\ Email: stephnomel@hotmail.com
}

Received January $30^{\text {th }}, 2013$; revised February $27^{\text {th }}, 2013$; accepted March $20^{\text {th }}, 2013$

Copyright (C) 2013 Nomel Paul Stephane Essoh. This is an open access article distributed under the Creative Commons Attribution License, which permits unrestricted use, distribution, and reproduction in any medium, provided the original work is properly cited.

\begin{abstract}
Since more than a decade sub-Saharan Africa has known a plenty of second-hands vehicles especially in francophone West Africa. These second hand vehicles made of personal fleet of cars constitute more than the $85 \%$ of the total number of automobiles in the region. That has contributed in a paradox way to businesses creation and increased the level of entrepreneurship in the automobile sector while it has been a help in performing the taxes collection and policy in ports. The invasion of these types of cars has led to West African ports cities especially Abidjan in Cote d'Ivoire to increase the demand. This paper tends to show the shipping practices of the second hand cars and the demand drawn by the socioeconomic environment. It illustrates the effects on port of Abidjan in Cote d'Ivoire with the local institutional and regulatory function in the shipping activities of the second hand cars. And so far, this study examines the evidence of how the invasion is organized since its import origins and zones to the sales stations and finally describe how this industry generates income for both public sector and private business owners.
\end{abstract}

Keywords: Port of Abidjan; Second Hand Vehicles; Shipping; Sole Dealers; Port Cities; Car Fleet

\section{Introduction}

Since more than two decades, the rapid needs of mobility in sub-Saharan Africa derived by the increasing population have developed an invasion of second-hands vehicles in African ports and major cities of the Sub-Sahara. If the economy of transportation remains a hot topic in governments agendas for balancing national and regional economic development, it is also inevitable for the private businessmen and middle entrepreneurs to consider automobile as a tool for not only a pleasure and leisure but also for a coherence between living standard, population growth, port cities space growth and their shipping business development. This dynamic necessity has consequently increased the demand of second hand vehicles which is partially derived by the low income earners and weak purchasing power of local citizens in buying new vehicles and cars.

These second hand vehicles made of personal fleet of cars constitute more than the $85 \%$ of the total number of automobiles in the region.
The invasion of these types of cars called "France au revoir", "congelées", or "surgelés de Belgique"2 has led to west African ports cities especially Abidjan in Cote d'Ivoire to increase the demand in shipping but also reorganize and expand its shipping traffic. In Cote d'Ivoire, this new business of second hand vehicles became a dynamic industry since 1996 with the liberalization policy of shipping and import of tourism used cars. It has improved the competitiveness of the port of Abidjan which in return reduced the long waiting time of vehicles transited through the port of Cotonou (Benin) and Lome

\footnotetext{
${ }^{1}$ Mostly imported from Europe via France second hand cars are known as the industrial waste that are no longer contributing to the socioeconomic and environmental needs of Europeans particularly of French citizens. They are seen as second hand frippery shipped from NGOs in the time of wars and starvation. France au revoir or congelés de Belgique are codes and expression of both shippers and consumers that are mostly from French speaking countries of West Africa (Benin, Burkina Faso, Cote d'Ivoire, Guinea, Mali, Niger, Senegal etc.).

${ }^{2}$ Mostly imported from Europe via Belgium ports to ports of French speaking countries of west and central Africa. That include the two Congo (RDC and Congo Brazzaville), Gabon, Cameroun and other central African countries.
} 
(Togo) that both remain the hubs of this new type of vehicles trade across Africa. As a thriving economic sector with several organized networks, this industry generates profits and income for private owners both in developed countries and in the developing ones and in the other hand does it as well for the public and government finance.

However, the paper tends to show the business scale of second hand vehicles and its effects on ports economic activities as well as its socio-economic consequences. The study attempts to develop the local institutional and regulatory function in the shipping activities of the second hand cars and so far, examine the evidence of how the invasion is organized and finally describe how this industry generates income for both public sector and private business owners.

Consequently, to complete our paper work, collection of data and information were made based on the literature revue of the topic development. It is mostly designed with shipping routes and itinerary of the second hand vehicles, from their purchasing places to countries of import and final demand. Questionnaire were filled by shippers and importers and interviews were made with firms owners, organizations managers, including all players involved in the shipping activities and trade of second hand vehicles not only at port level but also in the hinterland of the country.

Afterwards, the paper article is organized in three major parts. The first part examines how the second hand vehicle industry sector works and functions. It studies the structure of the activities and how the shipping routes including importation origins and export in the West African Atlantic coast especially how operations in intra-ports are organized. That includes the main maritime transportation companies involved in the second hand vehicle traffic and how the ports of Abidjan, of Cotonou, and of Lome play the key role.

The second part analyses the incentives behind the needs which makes the sales of the second hand vehicles a kind of business specialisation of the West African ports cities. By highlighting the demand and supply structures, it discusses the socioeconomic reasons that have contributed to the invasion and secular practices of second hand vehicles in Cote d'Ivoire.

The third part presents the effects of the second hand vehicles business and its specialisation's impacts on the fleet of new and development of road transportation. A section discusses the reorganisation from informal level to formal level of the market and how this activity sector created a new emerging class of businessmen establishing their firms alongside of quays of the ports. That involves the application process for license to operate and cargo transfer products which created various expertise and employment at the port of Abidjan.

\section{Structure of Distribution and Organisation of the Second Hand Vehicles Shipping}

The market structure and organisation of the shipping and transportation second hand vehicles are mainly developed by Ivoirian nationals and other Africans residing in overseas. The shipping activities were developed under the economic and financial constraints faced by most of African students in Western Europe or other individuals seeking to involve themselves in cars and automobile deals in order to support their financial subsistence and daily survivals. This new business and phenomenon explore some organizational levels that includes the origin of second hand vehicle and place of importation, shipping and route of container transport, the sales stations available in final destinations and competitiveness in local port market.

\subsection{Origin and Shipping Structure of the Second Hand Vehicle}

Started since earlier 1990s, the market structure of used cars and vehicles knew a considerable development in terms of new type of businessmen with cars fleets available in most important and attractive junctions and around roads in biggest cities of West African countries. Purchased with perpetual low prices, those used vehicles are managed by cars dealers who represent officially the industrial motors corporations which are running in a rude competition with affordable prices. This automobile booming called a special interest on German brands and their dealers since they seemed to be the most honest and less mafia-like. And furthermore, it is said that the German brands that are sold, match with local routes and practical roads and, correspond to the reality on the ground. That involves all their documents needed by the buyers to fill the formalities and customs clearance. Despite the fact that less of those cars flowing in African biggest ports are originated from Asia, Japanese brands hold a considerable appreciation and are practicable on the sub-Saharan African roads and routes. The business activities that are mostly run by overseas African residing abroad in order to remedy their financial situation are supported by their home compatriots and relatives who also desire in their side manage and sell those used cars.

Collecting vehicles from stations and the ambulatory search with door-to-door are the two major methods of collection of the second hand cars that traders use to facilitate the activities.

The first consists in the exposition of vehicles based on brand, usefulness, category, type and age on decorated 
spaces and places that allow importers and traders to have easy access in the fixed stations. Importers basically purchase the vehicles base on their needs and financial affordability.

The second method consists importers in searching and looking for the used vehicles in sales stations where information are provided from person to person or grapevine like, through website, newspapers and sometime with local radios. It appears unfortunate when things concern technical aspects. Mechanical failure or indefectible breakdowns of the used cars which mainly missed technical inspection and engine assessment due to the time constraints remain the core problem of this method that is somehow a technique that allows theirs operator to buy vehicles at revised costs and less than those from sale stations.

\subsection{Shipping and Route of Containerized Transport of the Second Hand Cars}

In order to avoid some damages such as loss of spare parts, breakage which may have extra costs to importers, two appropriate main modes of packing and conditioning systems are developed to proceed to the transportation of the used cars. The containerisation of second hand used vehicles and the multimodal transport system in forwarding the cars (refer to Figure 1 for structure).

The Containerisation and loaded bulk constitute the two conditioning and packing modes to send the vehicles to the port of Abidjan. The bulk system that consists in laying the cars on deck or in the ships bunker is the mostly used mode due to its lower cost, around $\$ 1000$ per vehicle comparatively to container that cost almost $\$ 2200$.

In 2007 , only $10 \%$ represent the 18,940 vehicles unloaded at the port of Abidjan comparatively to $15 \%$ of 2058 vehicles unloaded in 2006.

The multimodal transportation system is a type of transport that allows the second hand cars to go through traffic from the collection place to the distribution point. Ro-ro (roll-on-roll-off) ships and container ships are the main ships that navigate sea through the Atlantic Ocean in transporting the vehicles while double or three axle trucks carry them by roads in hinterlands.

Customs statistics indicated that companies such as Geodis Overseas, SDV-SAGA and Grimaldi are the main shipping companies involved in the import of the second hand cars (See Table 1).

However, between 2006 and 2007, this business was supported by the marginal growth of companies such as Atlantic S.A., GETMA and SIVOM that achieve most important variations to the port of Abidjan. The organisations that deal with berth cost at the port receive the vehicles and proceed to handling and warehousing of goods. But the vehicles may also be unloaded on the south quay as well on the north quay or fruit quay inside the seaport.

\subsection{Sales Stations in Final Destinations and Local Port Competitiveness}

Major cities across the mainland of the country constitute the identified places and market spaces to be won and the main destination of those second hand vehicles is Abidjan and its district peripherals. This has naturally set some nodes of distribution.

- Major Players of the market of the second hand vehicles

- Strategies of approaching customers

- Supply reinforcement in port sites and in sub-district of the city of Abidjan

- Competitiveness Aspect of the Port of Abidjan

- Establishment of fleets of cars in main inland cities

\subsubsection{Major Players of the Market of the Second Hand Vehicles}

The business of second hand vehicles sector identifies different types of players that are complementary despite that it exists differentiation in their business roles and objectives. Some of the major players of this sector make actively the business to resist and support its survival and development while others that are considered in their secondary role and existence are supported by the first group players. Customers from different social background operating in the transportation sector, importers, managers, government organisations and agencies and other tertiary players that mostly work on the vehicles in activities and operations constitute mostly the first group of business players (refer to Figure1).

The structure of this section indicates that $80 \%$ of the players composed by the sector run their public transportation business in urban and interurban area where people and good are transported. Private vehicles owners and workers and other organisations groups and private buses for supporting the transport of firms' personnel and workers are the last group players of the sector.

However, the shipping and transfer of the second hands vehicles through ports around the costal countries in vicinity has known a development while it has reduced the long waiting time as stated by $22 \%$ of the people interviewed. In the transaction process, importers either as companies venture or individuals with business operations of collection, transportation, and reception level, once purchased the second hands vehicles, mandate shipping and authorized dealers that sent them to port quays with the technical assistance from clearing forwarders, consignees and other shipping agents. Once arrived at the destination, the good (second hand cars) 


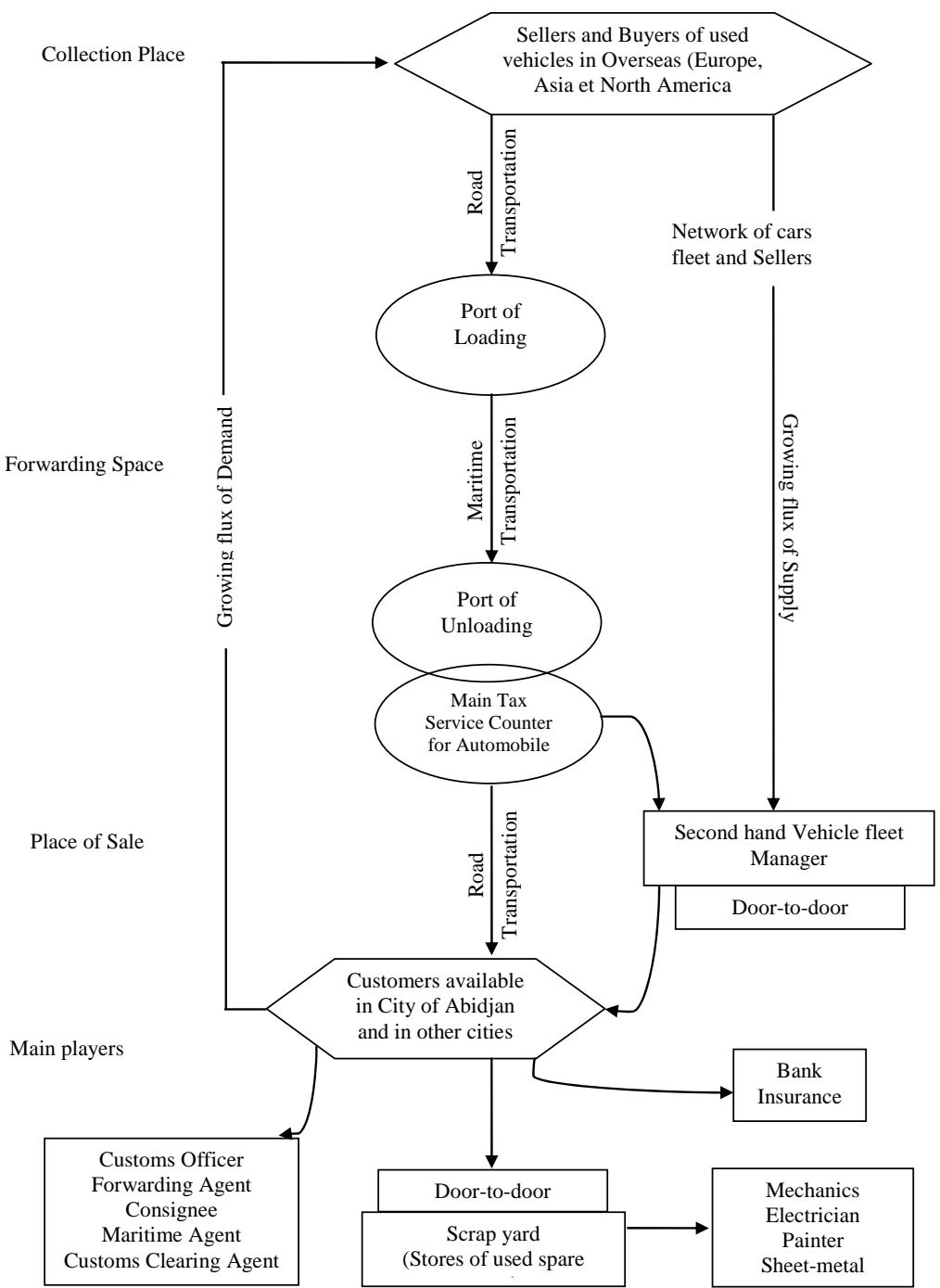

Figure 1. Structure of shipping activities and routes of second hand cars from collection place to final destination. Source: KABLAN, 2009.

Table 1. Main shipping companies and firms involved in import of second hand cars.

\begin{tabular}{|c|c|c|c|c|c|c|}
\hline \multirow[t]{2}{*}{ Firms } & \multicolumn{2}{|c|}{2007} & \multicolumn{2}{|c|}{2008} & \multicolumn{2}{|c|}{2009} \\
\hline & Number of traffic & $\%$ & Numbers of traffic & $\%$ & Numbers of traffic & $\%$ \\
\hline Atlantic S.A. & 560 & 2.95 & 312 & 1.73 & 252 & 2 \\
\hline Geodis Overseas & 3000 & 15.83 & 3207 & 17.78 & 3012 & 21.01 \\
\hline GETMA & 580 & 3.06 & 646 & 3.58 & 361 & 2.52 \\
\hline Grimaldi & 4500 & 23.75 & 4884 & 27.08 & 3914 & 27.37 \\
\hline MAERSK & 812 & 4.28 & 897 & 5 & 1109 & 6.41 \\
\hline SDV-SAGA & 4000 & 21.11 & 4613 & 25.58 & 4132 & 28.9 \\
\hline SIMAT & 797 & 4.20 & 769 & 4.26 & 808 & 6 \\
\hline SIVOM & 2018 & 10.64 & 2702 & 14.98 & 2613 & 4.95 \\
\hline SOCOPAO & 612 & 3.23 & 703 & 1.73 & 709 & 2 \\
\hline
\end{tabular}

Source: Custom Administration of Cote d'Ivoire, 2009. 
are set out and displayed in spaces around roads and streets of the city of Abidjan as well as in other inland major cities of the country in order to proceed to their sale. That also led a creation of new car fleet managers and jobs that took place from late 1997. Estimation of 1700 individuals carried out by our personal research and investigation conducted in 2010 reveal that most players and participants who are collectively or individually operating in the second hand vehicle business are unemployed individuals, students as well as some workers that see this type of business as their second source of income. The invasion of this activity sector has considerably absorbed a big part of unemployed and jobless people since. And professions of car fleet managers appeared in 1998 are continuously increasing as far as more than 2000 people are involved since 2010. Professional and social unions were equally set and interventions in securing their newly organisation and profession still know effects, attribution and restructuration. ARVO-YOP ${ }^{3}$, AGPA-CI ${ }^{4}$, $\mathrm{SYREVOCI}^{5}$ are the main trade and professional unions growing with their flouring activities and business expansion (see Figure 1).

Beyond the above corporations and professional unions, there are national and government bodies and agencies that regulate the activity sector like inspection and tax collection procedures (for second hand vehicles with 10 years old for small private cars and 15 years for buses and trucks) from the customs department. Others provide license code for external trade promotion and permission to importation and, intervene in the unloading service of car fleet at the port which is inspected by a private administration system known as Cote d'Ivoire Logistique and Societe Ivoirienne du Controle technique automobile.

\subsubsection{Strategies of Approaching Customers}

In order to attract customers to their product three basic business strategies were set.

Managers of car fleets set out and display outside their goods and products in chosen and designed large sites

\footnotetext{
${ }^{3}$ Association des Revendeurs de véhicules d'occasion de Yopougon (Association of Second hand vehicles Re-sellers of Yopougon). Yopougon is one of the biggest sub-district area of the business capital city of Abidjan. With more than 1 million of population, Yopougon remains a major sub-district with an independent municipal commune that possesses around 32\% of the economic activity of Abidjan.

${ }^{4}$ Association des Gestionnaires des Parcs Automobiles d'Abidjan (Association of car fleet managers of Abidjan). A corporate and trade union set up by individuals employed in the vehicles and cars sale and management service. Most operations offices are located around roads, highways and famous streets of city of Abidjan while some are located at the vicinity of the port of Abidjan.

${ }^{5}$ Syndicat des Revendeurs de véhicules d'occasion de Cote d'Ivoire(Trade Union of Second hand vehicles Re-sellers of Cote d'Ivoire). Seen as a registered national trade union for the defense of their corporate affairs.
}

bordering roads, avenues, traffic junctions, roundabouts, boulevards and streets in order to allow visitors, tourists and other busies to see and visit them.

The second strategy which is more aggressive consists in proceeding into door-to-door practices to express the performance of their products. It also develops appointment schedules where operations consist in seducing and claiming performance of second hand cars. Insisting outgoing phone calls are the practices reserved for connection with their clients and social networks.

The third part of their marketing strategies are build base on the wants and needs which are derived mostly from owners of communal cabs and city taxis incurporated with meter-counter. The second concerned point is expressly designed for vehicles and cars mostly sought and needed by their clients which basically focus on Japanese brands and with diesel engines system.

\subsubsection{Supply Reinforcement in Port Site and District of the City of Abidjan}

In the city of Abidjan, each district and commune record sellers, intermediaries and wholesalers involved in the activity and car fleets. In one of the biggest municipalities and commune of Abidjan known as Yopougon, car fleets are bordering the main roads and street. Namely from Siporex ${ }^{6}$ to Sideci while other expositions are set in opposite of Ficgayo ${ }^{7}$, at the street junction of rue Princesse, some stocked around the Nouveau Marché of the same municipality. Districts and municipalities such as Koumassi, Marcory, Port-Bouet and Treichville constitute the biggest showcases and store windows of second hand vehicles expo. Because of the vicinity of these communes with the port of Abidjan and its container terminal located at Vridi around Port-Bouet, the major part of car fleets are found there because of the importance role of boulevard Valery Giscard d'Estaing that linked the four municipalities. And economic players and operators mostly set up offices and premises in these communes and zones which registered new investors and entrepreneurs in the sector since 2010.

However, the shipping and invasion of second hand vehicles have gradually transformed the peripherals and rings roads of Abidjan into big stores with open-air and windows for cars and trucks where resellers run their businesses.

\footnotetext{
${ }^{6}$ Formally known as estate operator after the construction of buildings and housing in the sub-district of Yopougon in Abidjan, the name has been attributed to a large road junction and roundabout where sellers and other local informal traders run their sale units. This place is linked to the highway and to north motorway of the city of Abidjan.

${ }^{7}$ Located in the district of Yopougon, Figayo is a public vast site and place where public events, major trade expo, mega concerts and other official ceremonies are organized Port authority considers this site as an extended land of their economic performance.
} 


\subsubsection{Competitiveness Aspect of the Port of Abidjan}

Since 1997 both the municipal and port authorities tend to regulate the vehicle shipping and transportation sector. Importation of the second hand vehicles named as "France au revoir" to the port of Abidjan and its expansion in the city of Abidjan and in other mainland cities has been possible with the central government recommendation. And taking such a measure was a necessary policy in reinforcing the competitiveness. Although the performance of the port of Abidjan remains the gateway of maritime economic performance in West Africa coastal region, the reason was mainly due to the influence of the port of Lome in Togo and its lower pricing and flexible tax policy that were applied to the shipping and import of vehicles. Another reason dwells in its characteristics of being since 20 years the hub of unloading and throughputs service of second hand vehicles and where several West African imported goods with destination to Cote d'Ivoire were unloaded in ports of its neighbouring countries. Indeed, that led the country's customs department to access to a decree draft in 1996 by authorizing the shipping and importation of used cars through the port of Abidjan and reduce then the fraud recorded on the road traffic between Lome and Abidjan.

\subsubsection{Establishment of Fleet of Cars in Mainland Cities}

Several inland cities such San-Pedro (where we find the Port of San-Pedro), Bouake, and Soubre, Abengourou as well as Daloa have unlikely known development of new businesse owners and entrepreneurs and recorded an expansion of number of car fleets estimated at 12 units with 1300 vehicles. Despite that the city of Abidjan where the Port of Abidjan is the regional hub, almost ten other inland cities such Yamoussoukro (current political capital of Cote d'Ivoire), Man, Gagnoa, Sassandra, Korhogo, Adzope, Aboisso, Dimbokro, Daoukro and Divo have developed draft of creating and setting up car fleet which will however increase the level of shipping activities and business transaction.

\section{Market and Socioeconomic Analysis of the Invasion}

This part analyses the motivations behind the needs which makes the shipping of the second hand vehicles a kind of business specialisation in the West African ports cities. By highlighting the demand and supply structures and presenting the socioeconomic reasons that have contributed to the invasion and secular practices of second hand vehicles in Cote d'Ivoire, we will describe simultaneously the technical, economic and financial factors that involve in the raising of shipping market as well as discuss the formalized institutional frame in supply of sec- ond hand cars with Cote d'Ivoire as a destination.

The supply of second hand cars appears in meeting the growing demand and satisfaction of the population that are already living with low income and under pauperisation [1].

\subsection{Sales of Second Hand Vehicles as a Specialization in West African Ports Cities}

If the sale and usage of second hand vehicles became a secular practice in West African ports cities [2], it has helped the North to supply its used vehicles and increase the competitiveness of its trade exchange with the South since the shipping and sale of those vehicles remain an operational practice of western concessionaries and resellers.

Consequently, considering the high volume of the vehicles and all players that are involved in the shipping of the second hand vehicles, it was paramount for most West African authorities to liberalize the sector and design a free regulatory frame and policy to handle the market. This has contributed and transformed the business of second hand vehicle into a business specialization in all over ports cities ${ }^{8}$ of West African sub-region. More than 245,000 vehicles and thousand of trucks have been shipped and transferred to the port of Cotonou (Benin) in 2002. It led this type of activity becoming the first lucrative and profitable business of the port of Cotonou with a production of $10 \%$ of the GDP. The shipping of these cars mostly operated by more than fifteen firms where, main operators such as Grimaldi, Messina and Hual compete, has created more than 90,000 jobs. Handling service, trade, repair and maintenance of engines, and transport of vehicles represent 80,000 secondary line jobs and 15,000 direct jobs [3].

As far as used cars are imported from Europe, Asia and in some less extent cases from north America with their final invasion in fleets of West African seaports since 1980s, the port of Cotonou in Benin is the first port in Africa, being specialized with this business. This brought further problem like glut and congestion of fleet and spaces in its port that become circumstantially a place of business activities of the vehicles. Inevitably, other problems such as bribery, corruption and insecurity have been developed in the same seaport.

Apart from the above shipping firms competing, there are less known foreign companies like Lauritzen and other local transporters and shipping forwarders con-

\footnotetext{
${ }^{8}$ The Association Nationale Villes et Ports (Association Cities and Ports)_Port authorities and urban authorities and the ports and cities themselves will devolve maximum benefit from better dialogue. Since 1988, the International Association Cities \& Ports has brought together actors from port cities to deal with common issues concerning the development of port and city and the relationships as well as their implications for economic and urban development.
} 
trolled by Lebanese who are operating at the two extremities of the sector.

In Togo, the port of Lomé is one of the running hub of this flouring second hand cars industry where the port traffic increased a level of more than 120,000 units in 2004 after a recorded 50,000 vehicle in 1998. Its comparative advantage in developing nautical bases and tariff and cost challenging the port of Abidjan in Cote d'Ivoire and the port of Tema in Ghana has considerably reduced the competitive gap by its organization of cars fleets aiming to avoid saturation and congestion inside the ports. Both the port of Lomé and Cotonou in West Africa have attracted a big number of customers in their respect countries but also in other countries of the subregion, especially in francophone zones because of the type of port traffic and flexible price practices that have been developed since.

\subsection{Demand Analysis in Cote d'Ivoire}

The high demand of second hand vehicles in Cote d'Ivoire is derived from the problem of urban and interurban transportation of all cities where increasing population became huge and crucial. Remaining in the fact of major metropolitan cities, mobility development occurs with the life standard and spatial growth and development of cities as well as with people behaviors, customs and their daily practices [4,5].

The diversity of businesses and the multiple economic activities and the increasing distances between living areas and working or leisure zones have aggregately increase the transport service and second hand cars shipping industry in Cote d'Ivoire especially in biggest cities like Abidjan, Bouake, Yamoussoukro and Daloa. The diversification of economic activities in port cities led to more frequent and various mobility [6,7]. However, although it appears to be historically wide, the demand of second hand vehicles in Cote d'Ivoire is derived by several factors.

\subsubsection{Technical and Historical Factors}

The economic hardship and critical situation of purchasing power driven by the crisis of 1990s have contributed to the inaccessibility of new brand vehicles that since the colonial epoch operate under the rule and regulation of French Automobiles Manufacturers Committee. The supply and sales of new automobile vehicles in Cote d'Ivoire were exclusively and only the protectorate market of French automobiles manufacturers and dealers [8]. Consequently the new brand vehicles and other luxurious ones that knew a series of bureaucracy rules and suffered from high prices in sub-Saharan Africa with regular hard policy from customs authority, were only supplied to multinationals, biggest firms and national administrations agencies.

Until 1997, all the vehicles shipped to Cote d'Ivoire as the final destination were firstly transferred to the other ports of coastal countries such the port of Cotonou (Benin), port of Lomé (Togo) with some transited in some extents to landlocked neighboring countries such as Mali and Burkina Faso.

Today, the situation has been performed with the installation of government agency known as Guichet Unique Automatique (GUA) ${ }^{9}$. As a public service counter available inside the port of Abidjan with the laying out of unloading quays, its establishment in facilitating the operations, remains important development for a better handling service in the shipping activity in the country.

Although the industry of second hand vehicles in West Africa remains one of the old market sectors, it has been revaluated and developed by Cote d'Ivoire' students of overseas and supported by the unemployed citizens and other business men attracted by the Industry.

The socioeconomic and financial situation of relatives, students and friends emigrated and lived in Europe constitute another reason. For these individuals, involving in such operations bring not only financial independence but also regenerate income to them and for those living at home in Cote d'Ivoire and other West African countries as well as create business opportunities.

\subsubsection{Social and Political Reasons}

In some extents of understanding African context, owning or possessing a car is a deadly, luxurious and costly efforts and endeavours. Having successfully owned a private car is considered by general opinion and thinking as sign of high status and social success from several years of hard work and sacrifices.

For majority of the people, the invasion of second hand cars is regarded as an ultimate advantage and opportunity for not only people to cover a long distance in a few time but also for people who have lost their jobs after unsuccessful policy of Structural Adjustment (SA), High Indebted Poor Countries Initiative (HIPCI), etc., imposed by the international financial organisations and Breton wood institutions. The last group of this people accounting mainly families heads survive today because of their involvement in the business activity developed by the shipping and invasion of second hand vehicles in the sub region.

These represent important reasons and factors that drove out the new brand vehicles from the local and re-

${ }^{9}$ Decree and law No. 98-563 of October 14, 1998 on creation of government agency in reinforcing the tax collection with autonomous public service delivery inside port of Abidjan and its Terminals. 
gional market. And then equipped the car fleet of the sub-region with investment in buses of public transport, taxis cab, private cars for firms staff transportation, trucks for goods conveys, private or individual cars ownership and other urban and rural mini-buses which invaded the roads and motorways of West African countries.

In Cote d'Ivoire, the economic crisis of 1980s to 1990s followed by socio-political and military crisis occurred since 2002 remain the main sources of invasion and shipping of second hand cars. Moreover, the liberalization and the back out of government's obligations and its incapacity in bringing entire satisfaction to the formal needs of people mobility, has accelerated the emergence of the private sector. That led the government and public authority to tolerate the massive importation of second hand vehicles.

\subsubsection{Economic and Financial Motives}

Today, the economic crisis and growth of poverty led the shipping and sale of new brand vehicles less productive. And the liberalisation of the sector promoted by local high authority has motivated individuals and companies to restore their economic participation that generate independent revenues for both dealers and public government finance. This has developed the industrial networks more tight and heavy with various transport nodes and marketing segments inside seaports and in dry ports in hinterland. Today the business activity of second hand vehicles has become one of the booming sectors of port industry in sub-Saharan Africa and the first SMEs producing value-added Tax (VAT) and GDP for the economic growth of West African countries possessing seaports.

Everyone gain his own benefits especially in ports vicinity each player either informal or formal find inestimably his daily profits and accumulate enormous amounts through customs authority that are mostly seen as one of the influential decision-makers in tax collection and payment operations in the port. In the other hand the shipping of the used or second hand cars in port cities, has facilitated the growth of cars fleets, the installation of small and medium size enterprises in the transport industry, and has transformed a big number of the imported used cars into taxis cab, public buses, and private cars. It allows a big number of middle managers, workers and professionals as well as other individuals with middle and low income to acquire their own cars necessary for their private and comfortable mobility.

\subsection{The Usual Supply and Flux Zone}

The business growth at the port of Abidjan identified as the biggest hub of West Africa in term of TEUs and throughput remain factors of the important traffic development of the second hand cars in Cote d'Ivoire. Until today the supply and purchasing of second hand cars are monitored by importers and managers of car fleets that propose a series of various vehicles with diverse origins where the collection of these vehicles are made mostly in Europe and less in North America and Asian countries. They are in general forwarded to the port of Cotonou or Lome or to other West African ports cities like Abidjan and Tema (refer to Figure 2).

Indeed, the second hand vehicles imported mostly from Belgium where traders in Antwerp and Anderlecht markets and from France at the beginning knew a decline and end of race and as well, have encountered important competitors from Germany because of their fake metercounters, dubious or non-authentic cars registration papers and fanciful declarations in technical inspection of the vehicles.

Today, despite all, the sector that encountered anarchy and phobia drove by the unnumbered informal deal continue to know a well restructuration and business growth in the inland cities of Cote d'Ivoire restores the formal business activities within an institutional regulation.

This reduced since 2006 the competitiveness of the ports of Cotonou (Benin) and Lome (Togo) in their role of interface vis-a-vis of their clients and regular customers available in Cote d'Ivoire. Obviously that created other new jobs and employment in the city of Abidjan. The Guichet Unique Automobile operating at the Port of Abidjan provides statistics data about the investment in the sector that registered $12 \%$ as nationals of Cote d'Ivoire, $18 \%$ as both nationals from Benin and Togo, and as well other foreign nationals like Lebanese representing the $70 \%$ of the 325 importers that have been registered.

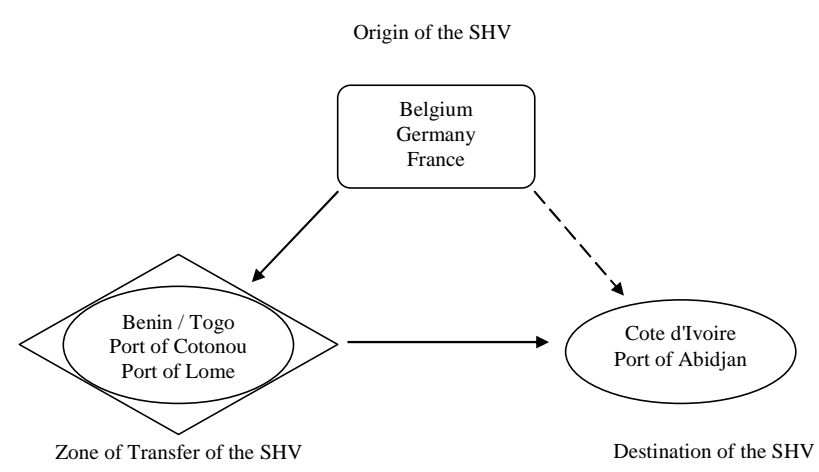

Figure 2. Nodes of concentration of second hand vehicles shipped to Abidjan shipping; Source: Designed by the author, base on investigation, Nomel (2011). 


\section{Effects of the Industry Development and Specialisation Impact of the Second Hand Vehicles Shipping}

The third part presents the effects of the second hand vehicles business and its specialization's impacts on the fleet of new and development of road transportation. The section outlines the reorganization from informal level to formal level of the market and how this activity sector created a new emerging class of businessmen establishing their firms alongside of quays of the ports. That include the application process for license to operate and cargo transfer products which created various expertise and employment at the port of Abidjan. Afterwards, this part develop as well some negative effects in terms of road degradation and environment cost $[9,10]$, the cause of the growing sector of second hand vehicles.

\subsection{Anarchic Occupation of Road Infrastructures and Degradation of Highways}

The business practices and experience of the sector show that roads and streets are occupied by resellers of second hand vehicles. And business owners mostly set up their businesses without any authorisation in occupying the sites and open-cut spaces. Definitively, the car fleets located and installed around roads, public sites and in other networks in the city of Abidjan identify and present three major problems.

- Too much vehicles occupy at least $47 \%$ of space inside the port of Abidjan which lead a periodical auctions of unused cars and those that have not been taken or did not meet inspection procedures by the customs department.

- Setting up premises and car fleets around roads and streets render less useful and more impracticable the roads and highways.

- Installation of the second hand vehicles around streets and roads in the city avoid and render mostly impossible the implementation of government project on "Clean and Green City” supported by the World Bank.

- Non-implementation of partial project on safety, emergency and rescue policy for some areas of the city of Abidjan that present high risks for the population.

Afterwards, the anarchic occupation of public sites and streets by cars fleets develop not only degradation of roads and highways but also cause intermediary damage of the environment where the second hand vehicles and cars constitute the main sources of pollution and other public health problems.

\subsection{Technical and Smugly Inspection for Second Hand Vehicles}

The shipping practice and the importation of the vehicles have developed and led to a rapid growth of automobiles industries in the port of Abidjan. This led unfortunately the city in uncontrolled services within the technical bureaus and regulatory offices. Too many cars are in irregular technical situation and other vehicles lack of their technical inspection which typically comes from the efficiency problem of SICTA ${ }^{10}$ in dealing with the growing sector.

Evidence shows that during technical check-up and mechanical operations at SICTA, inspection officers and technicians from this organisation get themselves corrupted by the vehicles and cars owners or drivers that in return make false declarations on vehicles and provide them with check-up and inspection license or certificate.

It is also clear that some of the car operators or vehicles owners borrow engines or spare parts from other automobiles and vehicles when visiting the SICTA office for inspection.

Besides, it is clear that crucial integrity situation in the public service delivery, constitutes one of the important factors of road accidents and environment pollution caused by the shipping and invasion of second hand vehicles. Since the technical or engine situation of those vehicles as described above that are generally hide from the public, always cost damages such as heavy and frequent traffic jams, thick and bushy smoke caused by exhausted cars engines.

Afterwards, in the country most roads accidents registered with deaths and serious injuries are caused by the lack of severe technical inspection of second hands vehicles according to the local government.

\subsection{Effects Analysis and Impact on New Brands of Vehicles}

In Cote d'Ivoire, although the market of new brand vehicle and automobile is dominated today by Asian manufacturers, more than two third of cars sold in the country are second hand vehicles.

The growing sector that knew a boom between 1997 and 1999 with more than 25,000 second hand vehicles against 9400 new brands each year contributed to the rapid renewal and restocking of car fleets replacing all second hand vehicles aged more than 10 years.

Today, despite the reducing number of car fleets managers (from 6700 to 5780 at the port of Abidjan and in other cities mostly driven by the socio-political crisis since 2002 which partly has increased unemployment, the second hand vehicles business sector registered a

\footnotetext{
${ }^{10}$ SICTA-Société Ivoirienne de Contrôle Automobile et Industriel, is a national private company that is authorized by the central government to control, check and inspect mechanically all automobiles, cars and other trucks before issuing license and certificate for their usage or circulation throughout country.
} 
number of 13,100 to 19,200 , around $48.5 \%$ of growth during the period of 2005 and 2008.

That consequently indicates the development of the second hand vehicles activity and its profits generated by car fleet managers not only inside the seaport but also around the city of Abidjan.

Since Japanese brands such Toyota firstly dominate the local market followed by the South Korean brands negotiate second position in these last five years, it is paramount to state the European brand such Renault and Peugeot lost their of market share (26.5\%) which is being contracted currently by Chinese series from Great Wall Motor like GWPeri settled up by Rimco and in the other side from Motors Tiger Motors with Chery operation since 2008 in the two ports cities (Abidjan and San Pedro) and inland like Bouake, Yamoussoukro and Daloa.

The last cited group of Chinese brands conquered gradually and successfully a market share because of their flexible practices in low cost and technology adapted to West African land and roads which mostly are not asphalted and tarred.

\subsection{Effects of Spare Parts of the Second Hand Cars and Fraud in the Sector}

The market of second hand cars has known some players and entrepreneurs that deal under personal and private operation in which, they manage to avoid financial charges and taxes allocated to authorized dealers and concessionaries. In such transactions where the spare parts of vehicles and cars are bought at low price at the same time with low service costs, everyone is met in "black market" also known as "a la casse", "aux ferrailles" or "a la rapide". Dealers and resellers manage to divert their clients attention or knowledge from the mother firm and company store.

All kind of engines, components and other cars spare parts of Japanese brands such as Toyota, Nissan, Mazda and European like Mercedes, BMW and Renault hardware, are available despite that American brands with affordable exchange rates mostly transited from the neighbouring Ghana, have started since 2007 flowing on the local market.

But the fraud practices that encountered the sector are not inevitable since other resellers and car fleet managers use in some ways and for their personal operations some cars and vehicles belonging to their clients and customers.

In other ways, some resellers work in collaboration with certain expatriates in Europe by importing nonguaranteed components for which prices are tripled and other fake quality spare parts of useless vehicles are initially subjected to recycling system. All these practices render the sector very risky.

\subsection{Analysis of Vehicles Replacement and Renewing of the Car Fleet in Cote d'Ivoire}

The growing sector that knew a boom between 1997 and 1999 with more than 25,000 SHV against 9400 new brands each year of this period contributed to the rapid renewal and restocking of car fleets replacing all second hand vehicles aged more than 10 years old. Between 1998 and 2008, almost in ten years the sector recorded an increase with average rate of $0.25 \%$ to $27 \%$ of vehicles aged less than 10 years.

Moreover, in the dilemma of second hand vehicles shipping activities or acquisition, if the age of vehicles does not seem to be a barrier or major reticence issue, it is absolutely the price that matters and constitutes the main factor for potential owners. And as far their correlation with personal satisfaction and usage do not involve heavy budget or high expense.

\subsection{Risks of Accidents and Breakdown}

The economic crisis of the 1980s occurred in the subSaharan African region followed by the socioeconomic hardship driven by the military and political crisis since 2002, has rendered the second hand vehicles imported from Europe a favourable and easy promise.

But looking analytically at the insights of this sector, there are absolutely some well planned risks that are involved since the technical manufacture and design of the second hand vehicles do not correspond to the climate and infrastructural environment of the African continent [11], especially with its roads and routes which until today become the reservoirs and tanks of European engines of old epoch. Today, sites became the trash bin of unused car components and still remain the heap or banger of imported old automobiles which do not facilitate the technical work and periodical visits of technicians and experts from government agencies. Since the frequent breakdown and operational activities of those engines and vehicles do not work in sustainable way in favour of their owners, it leads to frequent visits to mechanics and other technicians that in return exploit deadly the cases.

In the other hand, the crisis led to a degradation of roads and highways and rendered some of the routes very impracticable.

Afterwards, in Cote d'Ivoire, an average of 5500 roads accidents with more than 500 deaths and 10,000 serious injuries are caused by the lack of severe technical inspection according to the local journal [12].

\subsection{Efficient Restructuration of the Market System: From Informal to Formal}

The shipping market of second hand vehicles represents an important stake and challenge not only for social and 
economic sector but also plays crucial role in spatial development necessary for both cities and seaports [13, 14].

It appears therefore crucial and obvious for major players and beneficiaries to regulate the market and render the sector more competitive and formal [15-17]. Therefore a series of measures comes up to face the disorganisation and anarchic system that characterise the sector. And implementing such measures, reinforces as well juridical or business law system in order to restrengthens this activity that generate advantages and revenues for all players and stakeholders $[10,18,19]$. In this, regulatory frame like government decisions in redrafting and adapting the condition ${ }^{11}$ of customs clearance and registration of second hand vehicles were effective. And other orders in transferring technical competences ${ }^{12}$ to firms and agencies of transport sector were completed.

The interventions of public players and stakeholders such as Port authority, Customs authority, Guichet Unique Automatique and other tax collection services, Police, Ministry of Trade, Ministry of Economy and Finance, and other government agencies working in the field of environment preventing pollution, remain the necessary conditions in re-organising and restructuring the market system.

Private firms, companies and other agencies involved in the market sector both of shipping and operation activities of second hand vehicle until today are moralised about the damage effects and now provide more accurate solutions in issuing authentic license and certificates which decrease the number of counterfeit and imitation process in obtaining car license, and business certification or administrative formalities through bribery and corruption.

As effect, jobs have been created and raised of revenues generated by some specific activities in the port starting from collection places to the reception area where the Guichet Unique Automatique remains not only the engine system but also the backbone of decision and inspection of all goods transited at the port of Abidjan before its operation or usage on the local or hinterland market.

The administrative measures and decision taken by the central government to allow the shipping of second hand

\footnotetext{
${ }^{11}$ Decree and law No. 213/MEMEF/MEMT of August 2004 on the adaption and redrafting the systems of customs clearance and registration of second hand vehicles in Cote d'Ivoire.

${ }^{12}$ By law No. 254/MEMT/CAB of 18 August 2004 on transfer of production of activities of former DTT to SONATT (Société Nationale des Transports Terrestres). Decree No. 98-564 of October 14, 1998 on approbation of concession convention related to the project design, financing, construction, operation activities, coordination and the harmonization of the government agency Guichet Unique Automatique.
}

vehicles at the port of Abidjan have consequently brought a new expertise, efficiencies and more formal performances. These include:

- Industrialisation of the port of Abidjan;

- Creation of new jobs in shipping sector;

- Promotion of employment not only in transportation sector but in public service sector;

- Reinforcement and revalorisation of the old jobs (mechanics, iron workers painters, electricians, etc. see Figure 1);

- Economic independence and financial resources available for government in achieving development projects;

- Gradual recovery of economy through public construction of inland and distribution of energy and electricity to villages and remote zones of rural areas.

Restructuring and reorganizing the market of second hand vehicle from informal stage to formal level would definitively work in favour of new class of business men, bring new occupations to people. In shipping and invasion of second hand vehicles at port, new business and entrepreneurs establishing their activities on quays in ports and around streets, junctions and strategic big site of cities, declare a fierce competition with major players like car fleets managers, door-to-door sellers, spare parts and scrap merchants who also are working arduously to keep and maintain their influence in the sector.

\section{Conclusions}

Obviously, as we described though the shipping and importation of the second hand vehicle have been at first erupted in a anarchic way, a certain number of reasons and factors have been the main development of trade and business of used cars and vehicles until the institutional effective policy adopted to regulate the sector took place in Cote d'Ivoire.

The shipping and invasion of second hand vehicles in ports cities of coastal area of West Africa brought in their context valuable resources governments through tax collection inside and outside ports. The market created by the second hand vehicles in Cote d'Ivoire has allowed a great number of people and organizations to acquire a lot of means of mobility and transport at competitive and affordable costs.

The current specialization of coastal ports cities especially in three French speaking countries (Benin, Cote d'Ivoire and Togo) increase effectively the level of their respective ports performance and efficiency $[2,20]$.

In cote d'Ivoire the port of Abidjan increase its leadership in the sub-Saharan Africa by reorganizing the public service delivery systems which the creation of Guichet Unique Automatique appears as an engine with multitasks systems that facilitate the heavy tasks of port 
authority as a landlord. At its industrial level, the creation of small and medium size enterprises and other businesses at quays and inside terminals allow the port of Abidjan to gradually to promote entrepreneurship with creation of dry ports in its hinterland. The last integration of the port into logistics chain supply system, increasing number of port facilities (gantry cranes, the new construction of container terminal of Ile de Bouley) and the growth of international trade flow with a total containers traffic and of cargo handling (throughput volume) estimated at 1,257,652 TEUs in 2009 against 1,037,766 TEUs in 2010, all have determined the competitive market and efficiency $[21,22]$ of the port of Abidjan in coastal region of West Africa while dealing simultaneously with the shipping activities of second hand vehicles imported mainly from western Europe and Asia.

Although they constitute indispensable tools and means of access to territories and other lands, the second hand vehicles need to be frequently inspected in order to prevent roads security, environment degradation and people health costs. Rude and better selection of those vehicles from importers, shippers, managers is necessary to reduce fraud and avoid other collateral effects brought by the shipping and invasion of second hand vehicles in ports cities.

Based on the fact that vehicles and car drive an investment in infrastructure construction [23-26], and building new infrastructure generates new cities, developments are important factors in ports industrialization and modernization. Such modernization in ports implies the development of new port-functions, technologies and infrastructure capable to lead a competitive market of specializations in ports city of West African especially in Cote d'Ivoire. That process will obviously go with the relationship between port function and performance and city in term of spatial level that is related to city function and opportunity.

\section{Note}

This research aims to understand the importance of shipping of second-hand vehicles in West African ports and provide an overview of their role in socioeconomic and business development of port cities in the region.

However, this article refers to a partial integration of PhD study "Impact of Port Competitiveness and Efficiency on Regional Economic growth: The Empirical Case of the Port of Abidjan in West Africa" (under development) supervised by Prof. Song Bingliang, Director of the Research Center of Maritime Industries and Regional Economy, and Prof. Dr. Qu Linchi, Director of the Institute of Logistics Economics \& Management; both Faculty members of School of Economics and Management of the Shanghai Maritime University.

\section{REFERENCES}

[1] DSRP, "Strategy of Launching of Development and Poverty Reduction," Ministry of Economy and Finance Abidjan, 2009, p. 198.

[2] J. Debri, “The West African Port Systems: Global Insertion and Regional Particularities," Journal of Port Economics in EchoGeo.revue.org, Electronic Reference, Vol. 13070, No. 20, 2010, pp. 2-10.

[3] R. De Loynes, "Dossier of Cotonou, Voitures: Le Garage Benin Pousse Les Murs in Le Marin Hebdomadaire,” 2003. http//www.lemarin.fr

[4] M. Wolkowitsch, “Geographie Des Transports,” Armand Colin, Paris, 1992, p. 322.

[5] Conférence Européenne Des Ministères Des Transports CEMT, "Transport Et Développement Economique, Table ronde,” OCDE, Paris, 2002.

[6] G. Dupuy, "Automobile Territories,” Anthropos, Paris, 1996, p. 216.

[7] J. Verny, “Globalization and Sustainable Mobility,” In: G. Wackermann, Dir. Mondialisation en dossiers of Essays and dissertation, Ellipses, Paris, 2006, pp. 227-331.

[8] Groupe Etudes et Recherche Permanent sur l'Industrie et les Salaires de l'Automobile (GERPISA), Université d'Evry, "Permanent Research and Studies Group of Industries and Employees of Automobile Sector,” 2009. http://www.gerise.univ-every.fr

[9] M. G. H. Bell and B. Khalid, "The Port Sector in South Africa: Towards an Integrated Policy and Institutional Reform,” World Bank, Washington DC, 2007.

[10] E. Boubacha, D. Davoult and E. Gueguen, "City and Port: Change and Restructuration,” International Association Cities and Ports, Ministry of Transport and Housing, Dossier Bibliographique, 1997.

[11] A. Mair, R. Florida and M. Kenney, "The New Geography of Automobile Production: Japanese Transplants in North America,” Economic Geography, Vol. 64, No. 4, 1988, pp. 352-373.

[12] Le Nouveau Navire, "Le Grand Coup Des Transporteurs: $1^{\text {ere }}$ Edition Du Grand Prix Des Transporteurs,” No. 184, Abidjan, 13-19 January 2010, pp. 18-19.

[13] J. Marcadon, "Logique Et Transport Internationaux, Le Cas De La Filière Portuaire,” Geography Review of the East, Vol. 3, No. 4, 1989, pp. 251-258.

[14] G. Aldoney Vargas, "Le Dynamisme Des Investissements Portuaires Dans La Cité Maritime,” The 6th International Conference of Cities and Ports, Association Internationale De Ports Et Villes, Montevideo, 18-22 November 1997.

[15] J. H. N. Kablan, "The Ambivalent Dynamism of a Rapidly Expanding Activities of Vehicle in Ports in Cahier," D’Outre-Mer, Vol. 63, 2010, pp. 397-400.

[16] J. Alemany Llovera, "Pour Une Ville Portuaire Durable," The 6th International Conference of Cities and Ports, Association Internationale de Ports et Villes, Montevideo 18-22 November 1997.

[17] J. Bonnifait, “Dossier Port d'Abidjan,” Jeune Afrique 
Economy, No. 2238, 2006, pp. 43-100.

[18] Crook, Gary, "Evolution Du Cadre Institutionnel Et Réforme Portuaire,” 1st Conférence Panafricaine Des Ports, Abidjan, 10-12 December 2001.

[19] N. Van and C. Henriëtte, "Port Reform and Concessioning in Developing Countries," Maritime Economics and Logistics, Vol. 7, No. 2, 2005, pp. 141-155. doi:10.1057/palgrave.mel.9100129

[20] S. Addo, "Port Cities and the International Trade of Ghana,” African Urban Quarterly, Vol. 9, No. 1-2, 1994, pp. 53-68.

[21] E. Musso, M. Benecchio and C. Ferrari, "Ports and Employment in Port Cities," International Journal of Maritime Economics, Vol. 2, No. 4, 2000, pp. 283-311.

[22] R. J. Sanchez, J. Hoffmann, A. Micco, G. V. Pizzolitto, M. Sgut and G. Wilmsmeier, "Port Efficiency and International Trade: Port Efficiency as a Determinant of Maritime Transport Costs," Maritime Economics and Logistics, Vol. 5, No. 2, 2003, pp. 199-218. doi:10.1057/palgrave.mel.9100073
[23] C. Comtois and B. Slack, “Transformations De La MainD’Oeuvre Maritime,” Rapport Au Comité Sectoriel De La Main-D’Oeuvre De L'Industrie Maritime, Table Sectorielle De L’Industrie Maritime Du Québec, Québec, 2005, 78 p.

[24] C. Comtois, B. Slack, J. C. Lasserre and C. Manzagol, "Les Plates-Formes Multimodales En Zones Urbaines," In: D. Patier-Marque, Ed., L’Intégration Des Marchandises Dans Le Système Des Déplacements Urbains, Laboratoire D’Economie Des Transports, Lyon, 2000, pp. 323-328.

[25] J.-P. Rodrigue, B. Slack and C. Comtois, "Transportation and Spatial Cycles, Evidence from Maritime Systems," Journal of Transport Geography, Vol. 5, No. 2, 1997, pp. 87-98. doi:10.1016/S0966-6923(96)00073-7

[26] B. Slack, C. Comtois and J. C. Lasserre, "Les Systèmes Portuaires Et Les Villes: Comparaisons Entre Diverses Régions Du Monde,” In: D. Patier-Marque, Ed., L'Intégration Des Marchandises Dans Le Système Des Déplacements Urbains, Laboratoire D’Economie Des Transports, Lyon, 2000, pp. 319-322. 